\title{
THE ROLE OF FOREST FRAGMENTS IN SMALL MAMMAL CONSERVATION IN AN OIL PALM PLANTATION IN NORTHERN SARAWAK, BORNEO
}

\author{
JAYASILAN MOHD-AZLAN*; SALLY SOO KAICHEEN*; LISA LOK* and \\ MICHAEL J LAWES**
}

\begin{abstract}
In recent decades vast areas of Bornean rainforest have been converted to monocultures, particularly to oil palm. This study describes and compares the diversity and persistence of small mammal species in fragmented forests within an oil palm plantation. Small mammals were trapped over 44 sampling days using mist-nets, harp traps, and cage traps. A total of 39 species of small mammals were trapped, represented by 22 volant (bats) and 17 non-volant species. These species were represented by 29, 15 and 26 species, and controlling for sampling effort by rarefaction, 19, 15 and 14 species of small mammals in high conservation value (HCV) forests, forest edge, and in oil palm plantation, respectively. Species diversity was greatest in the HCV forests $\left(H^{\prime}=2.22\right)$, followed by oil palm plantation $\left(H^{\prime}=1.11\right)$, and then edge $\left(H^{\prime}=1.07\right)$. The smaller HCV forest (116 ha vs. $990 \mathrm{ha}$ ) contained more species than the larger forest (25 vs. 17 species). We attribute this to differences in species relaxation rates and the possibility that species density compensation has occurred in the smaller forest. This study demonstrates the conservation value of small forest fragments in oil palm plantations to maintaining native species diversity and the ecosystem services they provide.
\end{abstract}

Keywords: monocultures, HCV, diversity, persistence, bats, terrestrial small mammals.

Date received: 9 April 2019; Sent for revision: 26 April 2019; Received in final form: 17 June 2019; Accepted: 12 July 2019.

\section{INTRODUCTION}

Land-use intensification by agriculture is a major driver of the decline of biodiversity and critical ecosystem services and is an important environmental threat to biodiversity in Borneo (Foley et al., 2011; Brodie, 2016). The most important economic crop in this region is oil palm (Elaeis

\footnotetext{
Animal Resources Science and Management, Faculty of Resource Science and Technology, Universiti Malaysia Sarawak, 94300 Kota Samarahan, Sarawak, Malaysia.

E-mail: azlan@unimas.my

** School of Life Sciences, University of KwaZulu-Natal, P/Bag X01, Scottsville 3209, South Africa.
}

guineensis) and vast areas of primary and secondary rainforest have been converted to oil palm since the 1970s (Myers et al., 2000; Gaveau et al., 2014; MPOB, 2017). Malaysia accounts for more than $30 \%$ of the world's palm oil production (MPOB, 2017). Sarawak is considered the final frontier for oil palm expansion in Malaysia, as Sabah and Peninsular Malaysia have been saturated with oil palm plantations (MohdAzlan and Lawes, 2012). Consequently, the current rate of deforestation for oil palm production is greater in Sarawak than in Sabah and Peninsular Malaysia. Sarawak currently has 1.5 million hectares of oil palm, representing $27 \%$ of the total oil palm plantation area in Malaysia (5.8 million hectares) (MPOB, 2017). The present study was conducted 
in northern Sarawak, in the region of Miri, which has extensive oil palm plantations representing approximately $25 \%$ of the total area under oil palm in Sarawak.

Malaysia is one of four regional biodiversity hotspots in South-east Asia that has experienced rapid and largely unmonitored deforestation and habitat degradation since the early 1970s (Myers et al., 2000; Gaveau et al., 2014). The rapid increase in area of oil palm plantations has become the greatest immediate threat to biodiversity in Sarawak and South-east Asia (Wilcove and Koh, 2010; Canale et al., 2012; Gibson et al., 2013; Stibig et al., 2014; Yue et al., 2015; Ghazali et al., 2016; Petrenko et al., 2016; Sasidhran et al., 2016). The establishment of oil palm plantations is a particularly intensive process involving the clearing of native vegetation to bare soil.

A substantial proportion of Sarawak's wildlife, including $19 \%$ of the mammals (5\% of 98 bat species, five primate species, three medium- to largesized carnivores, 21 rodent species and two large herbivorous mammals), $20 \%$ of snake species and 6\% of bird species (Myers and Allen, 2009; Haas et al., 2013; Phillipps and Phillipps, 2016) are endemic to Borneo. Many of these endemics are niche specialists (Brodie et al., 2017). Although the effect of deforestation and habitat alteration on wildlife has been well documented under a broad range of circumstances in South-east Asia (Kinnaird et al., 2003; Koh and Wilcove, 2008; Fitzherbert et al., 2008; Sodhi et al., 2009; Koh and Sodhi, 2010; Wilcove and Koh, 2010; Brodie, 2016), the specific effects of oil palm expansion on wildlife communities remains poorly understood. In general, oil palm plantations support fewer forest species compared to primary and secondary forests and lower species richness (i.e. arthropods) than some agriculture crops (i.e. rubber, cocoa and coffee) (Fitzherbert et al., 2008; Azman et al., 2011; Petrenko et al., 2016). Rats (Rattus tiomanicus) are relatively more abundant in oil palm plantation, supporting some predator populations, including python, owls, and leopard cat (Rajaratnam et al., 2007; Fitzherbert et al., 2008).

In recent years, the palm oil industry has recognised the need for biodiversity-friendly oil palm plantations. The primary motivation for this is environmentally conscious consumers who demand agricultural products produced in an environmentally sustainable and socially responsible way (Paoli et al., 2010; Azhar et al., 2017). However, there is also a growing realisation that the vast spatial scale of, and agricultural practices used in, oil palm production, can irreparably damage ecosystem be functioning and services, ultimately to the detriment of palm oil productivity. In an attempt to address the latter, many large oil palm estates are required to retain and protect forest patches and accord them high conservation value
(HCV) status (Edwards et al., 2012). Areas that are unsuitable for oil palm or are inaccessible are often not cleared. This creates small fragmented forest patches that are often isolated within a vast oil palm plantation landscape. The isolated and small size of forest patches are not conducive to the long-term persistence of tropical mammals. Their isolation in a 'hostile' matrix impedes the movement of arboreal mammals (Peres, 2001), and their small size constricts home ranges of mammals, which ultimately can cause population decline and extirpation or extinction (Michalski and Peres, 2005; Gibson et al., 2013). In spite of their small size and scarcity, these HCV habitat fragments are the only hope for protecting the remaining biodiversity in oil palm plantations and to maintaining important landscape ecosystem functions and services. Determining the value of small residual $\mathrm{HCV}$ habitat fragments for maintaining biodiversity is essential for improving conservation management on current oil palm plantations.

In this study, we report the species richness and assemblage composition of volant (bats) and nonvolant small mammals in rainforest fragments on a large oil palm estate in northern Sarawak. There were insufficient fragments to rigorously test species-area and -isolation effects. Nevertheless, we examined the contribution of the available HCV forest patches to retaining and maintaining ecosystem functions and services by addressing the following questions: (1) does oil palm represent a barrier to the movement of small mammals, thus diminishing the ecosystem function value of these fragments? We predicted that bats use oil palm more than non-volant mammals, to which the oil palm boundary is a hard barrier, and (2) what species and guilds from HCV forest can live in oil palm (i.e. to whom the oil palm is not a species sink).

\section{MATERIALS AND METHODS}

\section{Study Site}

The study was conducted in northern Sarawak on the Saremas 1, Saremas 2 and Segarmas estates, within the Wilmar oil palm plantations $\left(1.5533^{\circ} \mathrm{N}\right.$, $\left.110.3592^{\circ} \mathrm{E}\right)$, approximately $60 \mathrm{~km}$ from Miri, the largest town in the region. The three estates (16 829.76 ha) are managed according to the Roundtable on Sustainable Palm Oil (RSPO) Principles and Criteria that aim to ensure environmentally sound management of oil palm plantations. Sampling was conducted on transects, from the centre of HCV forest patches, traversing the forest-oil palm boundary or ecotone, and extending $300 \mathrm{~m}$ into the adjacent mature (20 years old, planted in 1995) oil palm plantation. Narrow riparian vegetation has been retained on Saremas estate but this vegetation is dominated by weeds and vines. There are three longhouses 
on the estate, and it is surrounded on all sides by other oil palm plantations, so that oil palm is the most continuous habitat in any direction. Two HCV forest fragments have been retained on Saremas estate: Bukit Durang Conservation area (989.86 ha) and another smaller HCV forest - Saremas 1 (116.28 ha; Figure 1). These fragments comprise secondary forest dominated by species from the families Euphorbiaceae, Leguminosae, Dipterocarpaceae and Moraceae.

Non-volant and volant small mammals (bats) were sampled on six separate occasions targeting all groups of small mammals from 2013-2015 for a total of 44 days (2-5 November 2013, 14-19 January 2014, 4-12 April 2014, 12-21 August 2014, 13-21 January 2015, 11-17 April 2015). The total sampling effort in forest and oil palm was the same - 1407 trap hours (cage trap), 4428 net-hours (mist-net) and 739 trap hours (harp trap). While at the forest edge sampling effort was 470 trap hours (cage trap), 1476 net-hours (mist-net) and 247 harp trap hours. Bats and nonvolant small mammal species were sampled by trapping along three $600 \mathrm{~m}$ transects (from forest interior, across the forest-oil palm boundary and into oil palm) in each sampling period. All harp traps, cage traps and mist-nets were placed at $100 \mathrm{~m}$ intervals along the transects $(100 \mathrm{~m}, 200 \mathrm{~m}$, and 300 m), starting $300 \mathrm{~m}$ into the forest and ending $300 \mathrm{~m}$ into the adjacent oil palm, and including sampling at the edge in the ecotone between forest and oil palm plantation. Mist-nets of mesh size 3 and 4, were used to sample both frugivorous and insectivorous bats. Seven mist-nets were set up along each transect, with one net at each sample distance. The nets were set at 2-5 m height and were checked every $2 \mathrm{hr}$ daily from 18 h00 to 06 h00. A total of 126 mist-nets were set up along the 17 transects (9 in Saremas 1 HCVF and 8 in Bukit Durang) resulting in 10332 mist-netting hours. Harp traps were used to capture specifically insectivorous bats, as these bats are able to avoid mist-nets using echolocation. Two harp traps were used during the first sampling period, six harp traps during the second and third sampling period, three harp traps in the fourth sampling period and two harp traps in the last two sampling periods. Total harp trapping hours were $1725 \mathrm{hr}$ (opened $12 \mathrm{hr}$ a day). The harp traps were rotated among the transects and sampling points on the transects during each sampling period. The harp traps were set near to mist-nets along the transect lines. A total of 168 cage traps were set in each sampling period ( 14-28 cage traps per transect) and baited with a combination of four different types of bait (banana, pineapple, oil palm fruit and peanut). Cage traps

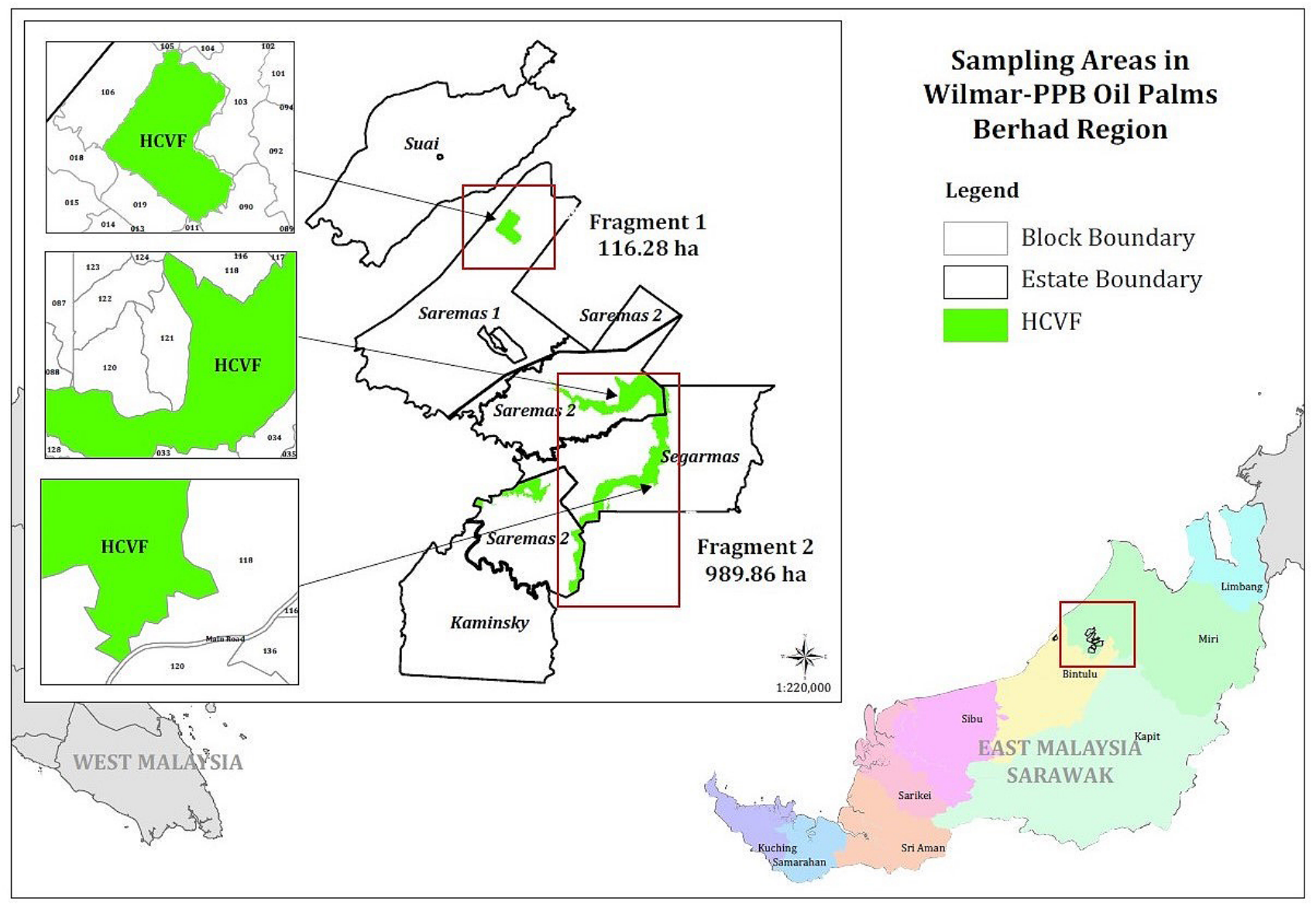

Figure 1. Map of Wilmar Oil Palm Plantation, Miri, Sarawak. Boxes indicate the location of high conservation value (HCV) forests of Saremas 1 and Bukit Durang. 
were checked twice daily (10 h00 and 17 h00) and total cage trapping effort was 3284 trap days.

\section{Statistical Analyses}

Analyses were conducted using $\mathrm{R}$ statistical software version 3.5.2 (R Core Team, 2017).

Species accumulation curve (SAC). SAC was estimated with the package 'vegan' (Oksanen et al., 2007; Oksanen, 2011). It describes the cumulative species richness with increasing sampling effort. It is used to determine if sampling saturation has been achieved, i.e. whether all species in the community have been detected. The mean and standard deviation of SAC are calculated from random permutations of the data based on sampling without replacement (Gotelli and Colwell, 2001). Sampling effort differed between forest and oil palm and the forest edge or ecotone and expected species richness was computed using the rarefaction method. In this method, species richness is estimated from the accumulation of the number of individuals with sampling effort, instead of from the number of sampling days at a particular sampling site (Oksanen et al., 2007; Oksanen, 2011; Colwell et al., 2012). Rarefaction estimates of species richness were computed using the software EstimateS 9.1.0 (Colwell, 2013).

Shannon's $\left(H^{\prime}\right)$ and Simpson's diversity $(D)$ indices. Diversity indices were estimated using the $\mathrm{R}$ packages 'vegan' (Oksanen et al., 2007; Oksanen, 2011) and 'betapart' (Baselga and Orme, 2012). Shannon's index is widely used to determine species diversity, while Simpson's index estimates species evenness (Peet, 1975; Nagendra, 2002; Keylock, 2005).

Dissimilarity indices. Sampling effort differed between the different sized forest patches. The total sampling effort in Saremas 1 (116 ha) was 1624 cage trap days, 3780 mist-net hours and 885 harp trap hours, while in Bukit Durang (990 ha) there were 2100 cage trap days, 6552 mist-net hours and 840 harp trap hours. Similarity between two communities is considered high when they have many shared or common species. Bray-Curtis Dissimilarity (BCD) indices (Bray and Curtis, 1957) were calculated using the R package 'vegan' (Oksanen et al., 2007; Oksanen, 2011). The calculated dissimilarity indices range from $0-1$ where 0 is identical species composition between two communities and 1 represents no species shared between the communities. Similarity between communities can obtained by:

$$
S=1-D
$$

where $S$ is similarity between communities and $D$ is dissimilarity between the communities.
Relative abundance (RA). The recorded bats and other small mammals were divided into three categories, namely: omnivorous non-volant small mammals, frugivorous and nectarivorous bats, and insectivorous bats. The relative abundance of species in each category were calculated for each habitat (forest, forest edge, oil palm) using the packages 'funrar' and 'ade4' (Dray and Dufour, 2007; Grenié et al., 2017).

\section{RESULTS}

A total of 856 small mammal individuals were trapped in the three habitats (forest, forest edge and oil palm) comprising 764 bats and 92 nonvolant small mammals (Table 1). Thirty-nine species of small mammal, from 11 families were recorded; 22 species of bats (six species of frugivorous and nectarivorous bats, and 16 species of insectivorous bats) and 17 species of non-volant small mammals dominated by Rodentia and Scadentia. This represents approximately $24 \%$ of bat species and $21 \%$ of non-volant small mammal species in Borneo. Among the habitats, the most species ( $\mathrm{n}=29$ species) were recorded from HCV forests, followed by oil palm plantation $(n=26)$ and forest edge $(n=15)$ (Table 1). Rarefaction estimates of species richness partially confirmed these richness trends, with plantation and the forest edge being similar but lower in richness than HCV forests (Table 1; Figure 2). Oil palm plantation had the greatest relative abundance with 488 individuals, while 257 and 111 individuals were trapped in HCV forests and at the forest edge, respectively. Bat species were mostly trapped in $\mathrm{HCV}$ forests and oil palm plantation with 16 recorded from both habitats, and nine species at the edge. Non-volant small mammals were mainly found in HCV forests (13 species), and in oil palm plantation (10 species) and at the edge (six species) (Table 1). Eight species, including three species of bats and five species of non-volant small mammals (20\% of all recorded species) were trapped exclusively in HCV forests, two species (one bat and one nonvolant; 5\%) only at the edge, and six species (four bats and two non-volant; 15\%) were only found in oil palm plantation (Table 1).

Even though more small mammal individuals were trapped in the oil palm plantation, there was no significant difference in the number of individuals trapped between habitats [ANOVA: $\mathrm{F}_{(2,114)}=0.679$, $\mathrm{p}>0.05$ ]. The lesser dog-faced fruit bat [Cynopterus brachyotis (Müller, 1838)] was the most abundant species with 568 individuals, while 15 species were only trapped once during the study (Table 1). Among the recorded small mammals, only the bats and species from the Tupaiidae are protected (P) in Sarawak. Seven species are of conservation importance (18\%). The Dayak fruit bat [Dyacopterus 
TABLE 1. THE LIST OF BATS AND NON-VOLANT SMALL MAMMALS AT WILMAR OIL PALM

PLANTATION, MIRI, SARAWAK

(relative abundance from forest, edge, oil palm plantation, species protection, conservation status in Peninsular Malaysia, Sarawak, Sabah, and from the IUCN Red List 2019, and the number of recaptured individuals)

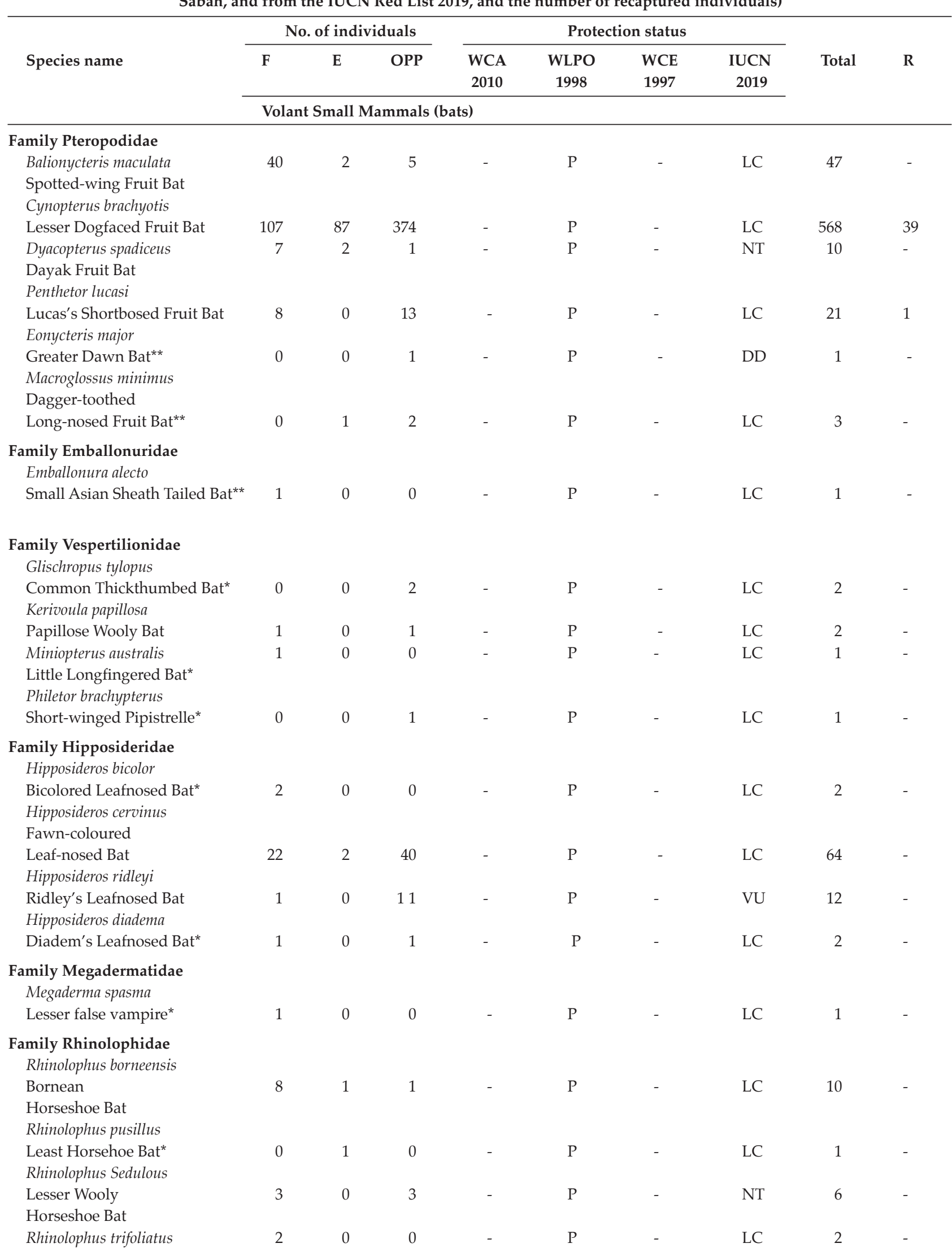


TABLE 1. THE LIST OF BATS AND NON-VOLANT SMALL MAMMALS AT WILMAR OIL PALM

PLANTATION, MIRI, SARAWAK

(relative abundance from forest, edge, oil palm plantation, species protection, conservation status in Peninsular Malaysia, Sarawak, Sabah, and from the IUCN Red List 2019, and the number of recaptured individuals) (continued)

\begin{tabular}{|c|c|c|c|c|c|c|c|c|c|}
\hline \multirow{3}{*}{ Species name } & \multicolumn{3}{|c|}{ No. of individuals } & \multicolumn{4}{|c|}{ Protection status } & \multirow{3}{*}{ Total } & \multirow{3}{*}{$\mathbf{R}$} \\
\hline & $F$ & $\mathrm{E}$ & $\overline{\text { OPP }}$ & $\begin{array}{l}\text { WCA } \\
2010\end{array}$ & $\begin{array}{c}\text { WLPO } \\
1998\end{array}$ & $\begin{array}{l}\text { WCE } \\
1997\end{array}$ & $\begin{array}{c}\text { IUCN } \\
2019\end{array}$ & & \\
\hline & \multicolumn{7}{|c|}{ Volant Small Mammals (bats) } & & \\
\hline \multicolumn{10}{|l|}{ Trefoil Horseshoe Bat } \\
\hline \multicolumn{10}{|l|}{ Family Nycteridae } \\
\hline Javan Slit-faced Bat & 2 & 2 & 2 & - & $\mathrm{P}$ & - & VU & 6 & - \\
\hline \multicolumn{10}{|l|}{ Family Molossidae } \\
\hline Mops mops & 0 & 0 & 1 & - & $P$ & - & NT & 1 & - \\
\hline \multicolumn{10}{|l|}{ Malayan Free-tailed Bat* } \\
\hline Volant Diversity index & 1.70 & 0.61 & 0.73 & & & & & & \\
\hline \multirow[t]{2}{*}{ Volant Evenness Index } & 0.70 & 0.23 & 0.30 & & & & & & \\
\hline & \multicolumn{9}{|c|}{ Non-volant Small Mammals } \\
\hline
\end{tabular}

\section{Family Tupaiidae}

Tupaia dorsalis

Striped Treeshrew*

Tupaia minor

Lesser Treeshrew*

Tupaia picta

Painted Threeshrew

Tupaia splendidula*

Ruddy Treeshrew

Tupaia tana

Large Treeshrew*

Family Sciuridae

Dremomys everetti

Bornean Mountain

Ground Squirrel ${ }^{* *}$

Callosciurus notatus

Plantain Squirrel*

Sundasciurus lowii

Low's Squirrel ${ }^{*}$

$\begin{array}{lll}1 & 0 & 0 \\ 0 & 1 & 2 \\ 6 & 0 & 1 \\ 1 & 0 & 0 \\ 1 & 0 & 0\end{array}$

Family Muridae

Maxomys baeodon

Small Bornean Maxomys ${ }^{* *} \quad 0 \quad 0$

Maxomys rajah

Rajah Sundaic Maxomys $^{* *} \quad 1 \quad 0$

Maxomys whiteheadi

Whitehead's Spiny Rat ${ }^{* *}$

Mus musculus

Asian House Mouse

Rattus argentiventer

Ricefield Rat**

Rattus exulans

Polynesian Rat

Rattus rattus

House Rat

Rattus tiomanicus

Malaysian Field Rat

Sundamys muelleri

Muller's Sundamys

P P

LC

7

P P

LC

P

P

LC

$\begin{array}{lll} & 1 & \\ 5 & 3 & 8\end{array}$


TABLE 1. THE LIST OF BATS AND NON-VOLANT SMALL MAMMALS AT WILMAR OIL PALM

PLANTATION, MIRI, SARAWAK

(relative abundance from forest, edge, oil palm plantation, species protection, conservation status in Peninsular Malaysia, Sarawak, Sabah, and from the IUCN Red List 2019, and the number of recaptured individuals) (continued)

\begin{tabular}{|c|c|c|c|c|c|c|c|c|c|}
\hline \multirow[b]{2}{*}{ Species name } & \multicolumn{3}{|c|}{ No. of individuals } & \multicolumn{4}{|c|}{ Protection status } & \multirow[b]{2}{*}{ Total } & \multirow[b]{2}{*}{$\mathbf{R}$} \\
\hline & $\mathbf{F}$ & $\mathbf{E}$ & OPP & $\begin{array}{l}\text { WCA } \\
2010\end{array}$ & $\begin{array}{c}\text { WLPO } \\
1998\end{array}$ & $\begin{array}{l}\text { WCE } \\
1997\end{array}$ & $\begin{array}{r}\text { IUCN } \\
2019\end{array}$ & & \\
\hline $\begin{array}{l}\text { Non-volant } \\
\text { Diversity Index }\end{array}$ & 2.19 & 1.63 & 1.91 & & & & & & \\
\hline $\begin{array}{l}\text { Non-volant } \\
\text { Eveness Index }\end{array}$ & 0.86 & 0.78 & 0.81 & & & & & & \\
\hline Total species & 29 & 15 & 26 & & & & & 39 & \\
\hline
\end{tabular}

Estimated

Species

(Rarefaction) $19 \quad 15 \quad 14$

\begin{tabular}{lllllll}
\hline Total Individuals & 257 & 111 & 488 & 856 & 40 \\
\hline
\end{tabular}

Overall Diversity

Index $2.22 \quad 1.07 \quad 1.22$

Overall Evenness

Index $\quad \begin{array}{lll}0.79 & 0.38 & 0.40\end{array}$

Note: F - Forest; E - Edge; OP - oil palm plantation; WCA - Wildlife Conservation Act 2010; WLPO - Sarawak

Wild Life Protection Ordinance 1998; WCE - Wildlife Conservation Enactment 1997; P- protected;

"- - "not protected; IUCN 2019 - The IUCN Red List of Threatened Species; DD - data deficient;

LC -Least Concern; NT - Near Threatened; Vu - Vulnerable; R - Recaptured individuals.

*Species which were only recorded in high conservation value (HCV) Forest Saremas 1.

** Species which were only recorded in HCV Forest Bukit Durang.

spadiceus, (Thomas, 1890)], lesser woolly horseshoe bat (Rhinolophus sedulus, KAnderson, 1905), Malayan free-tailed bat [Mops mops, (de Blainville, 1840)] are Near Threatened (NT); while Ridley leaf-nosed bat [Hipposideros ridleyi, (Robinson and Kloss, 1911)], Javan slit-faced bat (Nycteris javanica, [(E. Geoffroy, 1813)], Rajah Sundaic Maxomys (Maxomys rajah, Thomas, 1894), and Whitehead's Rat (M. whiteheadi, (Thomas, 1894)) are listed as Vulnerable (VU) by the International Union for Conservation of Nature's Red List (IUCN) 2019 (Table 1). We did not achieve sampling saturation for bats and non-volant small mammals in this study (Figure 2).

\section{Species Diversity Indices}

Diversity $\left(\mathrm{H}^{\prime}\right)$ was significantly greater $(\mathrm{P}<0.05)$ in $\mathrm{HCV}$ forests $\left(\mathrm{H}^{\prime}=2.22\right)$ than oil palm plantation $\left(\mathrm{H}^{\prime}=1.11\right)$ and the edge $\left(\mathrm{H}^{\prime}=1.07\right)$ (Figure 3$)$. The diversity of non-volant small mammals was greater than the diversity of bats in $\mathrm{HCV}$ forests $\left(\mathrm{H}^{\prime}=2.19\right)$, oil palm plantation $\left(\mathrm{H}^{\prime}=1.91\right)$ and edge $\left(\mathrm{H}^{\prime}=1.63\right)$ (Figure 3). Evenness (D) was also significantly greater $(\mathrm{P}<0.05)$ in $\mathrm{HCV}$ forests $(\mathrm{D}=0.79)$ than the oil palm plantation $(D=0.40)$ and edge $(D=0.38)$. Species were more evenly distributed among non-volant small mammals in $\mathrm{HCV}$ forests $(\mathrm{D}=0.86)$ compared to bats $(\mathrm{D}=0.70)$ (Figure 3).

\section{Community Species Similarity among between Habitat Types}

The communities in the habitat types were clustered into two groups, with communities in the oil palm plantation and $\mathrm{HCV}$ forests being more similar to each other $(65.46 \%)$ than to the community at edge (Similarity: forest vs. edge $=$ $50.00 \%$; edge vs. oil palm plantation $=63.42 \%$ ) (Figure 4). Conversely, the non-volant mammal communities in the oil palm plantation and at the edge had higher similarity $(62.5 \%)$ compared to the community in HCV forests (Similarity: forests vs. edge $=42.10 \%$; forests $v$ s. oil palm plantation $=$ $60.87 \%$ ); while the bat communities showed similar habitat cluster patterns to the overall species pattern (Similarity: forests vs. edge $=56.00 \%$; forests vs. oil palm plantation $=68.75 \%$; edge vs. oil palm plantation $=64.00 \%$ ) (Figure 4$)$.

\section{Guild Similarity among Habitat Types}

All the diet guilds (omnivorous non-volant small mammals, frugivorous and nectarivorous bats, and insectivorous bats) were observed in all the habitats types. The frugivorous and nectarivorous bat guild was the most abundant guild in all three habitats. Insectivorous bats were more abundant in 
(a)

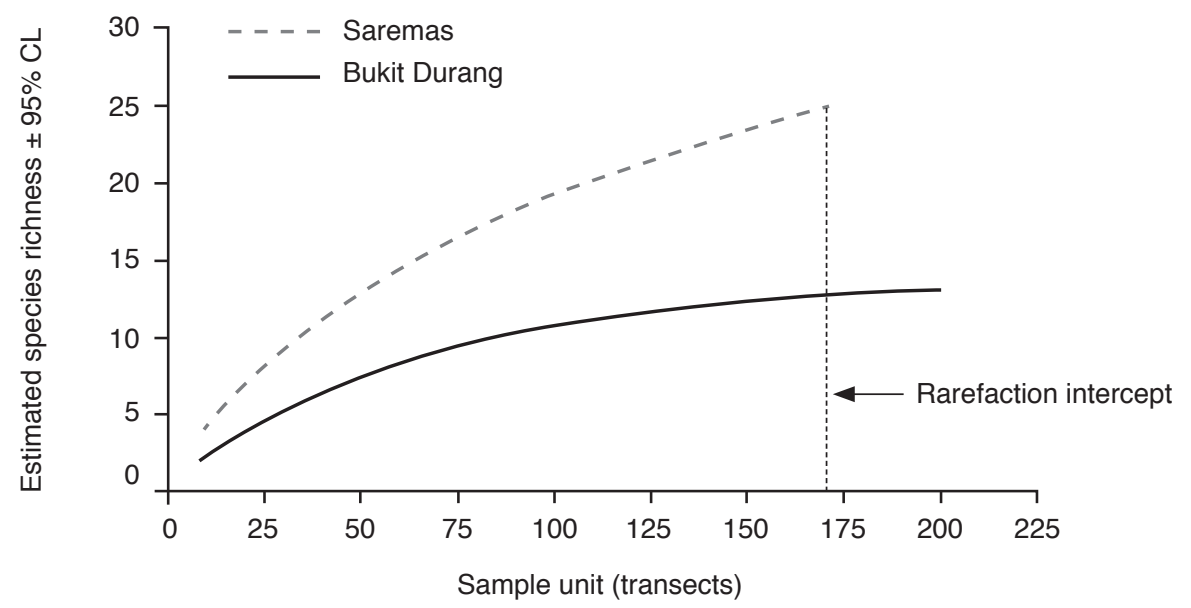

(b)

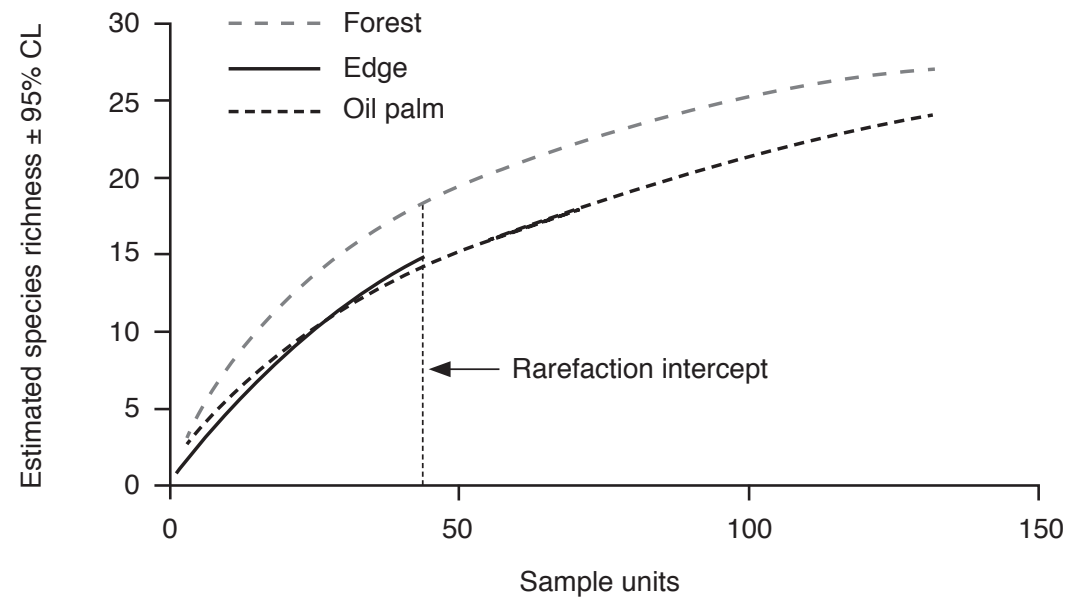

Figure 2. The species richness rarefaction curves for bats and non-volant small mammalian combined over 44 days of sampling for (a) the two high conservation value (HCV) forests, and (b) the habitats (forest, edge and oil palm). Curves show species accumulation over the study and the rarefaction estimates of species richness (extrapolated at the lowest number of sampling units).

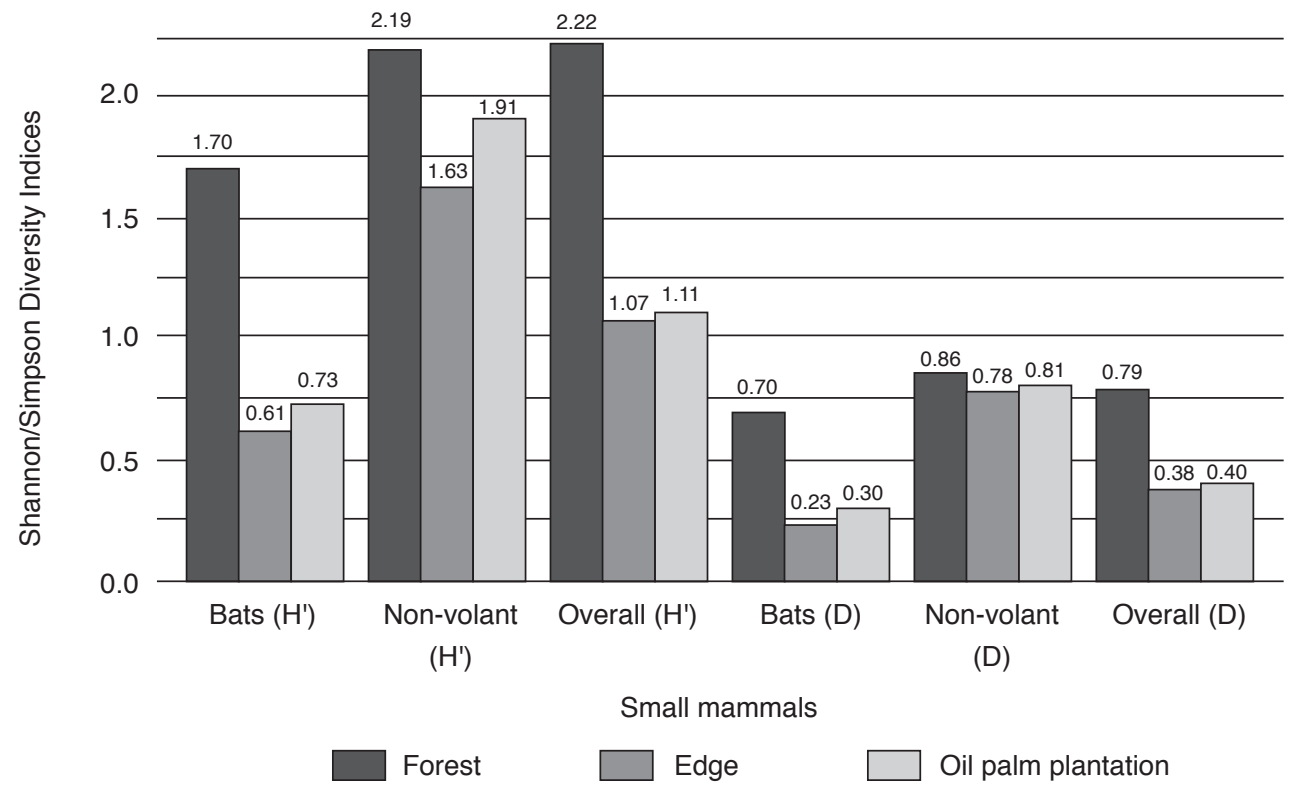

Figure 3. The Shannon's $\left(H^{\prime}\right)$ and Simpson's (D) Diversity Indices based on total samples for bats and non-volant small mammals in forest, edge, and oil palm plantation. 
forests followed by oil palm plantation, and then the edge (Figure 5). The 764 captured bats represented 650 frugivorous and nectarivorous bats and 114 insectivorous bats. The abundance of omnivorous non-volant mammal species decreased along the habitat gradient from forest interior to oil palm plantation interior.

\section{Comparison of Small Mammal Diversity between Saremas 1 HCV (116.28 ha) and Bukit Durang HCV (989.86 ha) Forests}

The small mammal communities in Saremas 1 and Bukit Durang were $46.3 \%$ dissimilar. Twenty- four species were trapped only in either Saremas 1 or Bukit Durang (Table 1). This included six species of non-volant small mammal, and eight bat species trapped in Saremas 1; while six species of nonvolant small mammal and four species of bats only were trapped in Bukit Durang (Table 1).

Mammal diversity was lower and species richness was greater in the smaller $\mathrm{HCV}$ forest Saremas 1 (Table 2). There were more frugivorous and insectivorous bat species in Saremas 1 than Bukit Durang, but more omnivorous non-volant small mammals in Bukit Durang (Table 2). The evenness of species abundance was greater for all guilds in Bukit Durang (Table 2).

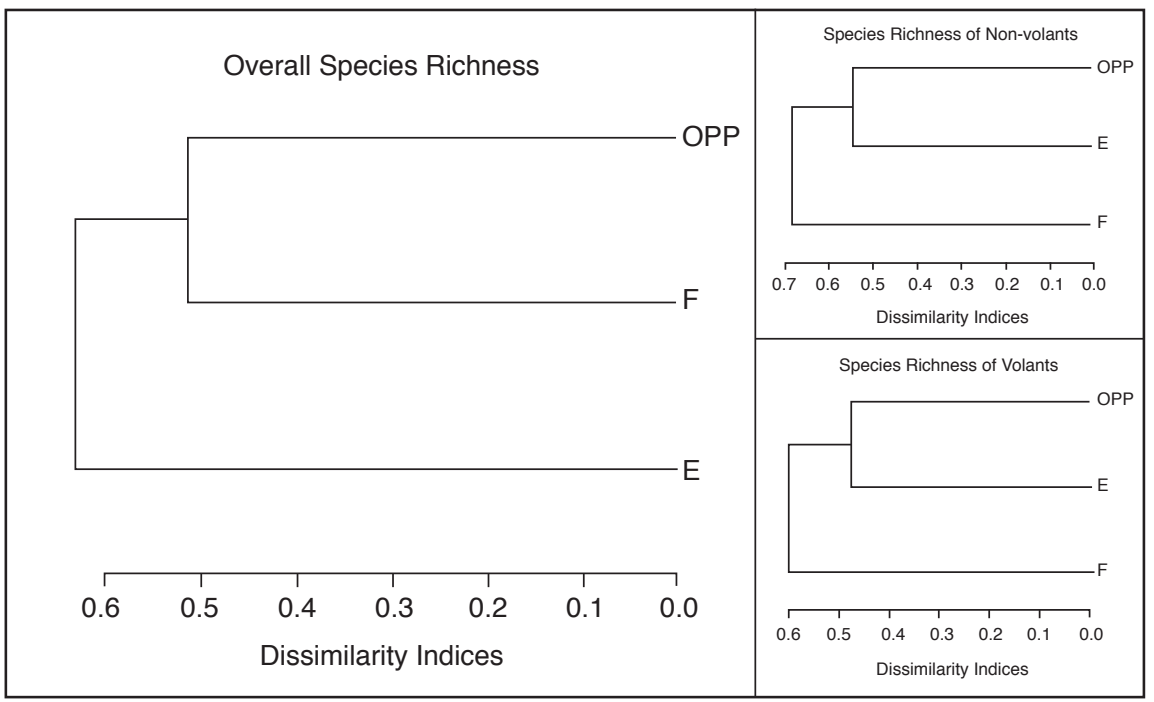

Figure 4. Cluster analysis based on the abundance of the 39 small mammal species recorded in forest $(F)$, edge (E), and oil palm plantation (OPP) at Wilmar, Saremas estate, Miri. The dendrogram was constructed using the Bray-Curtis Dissimilarity Index.

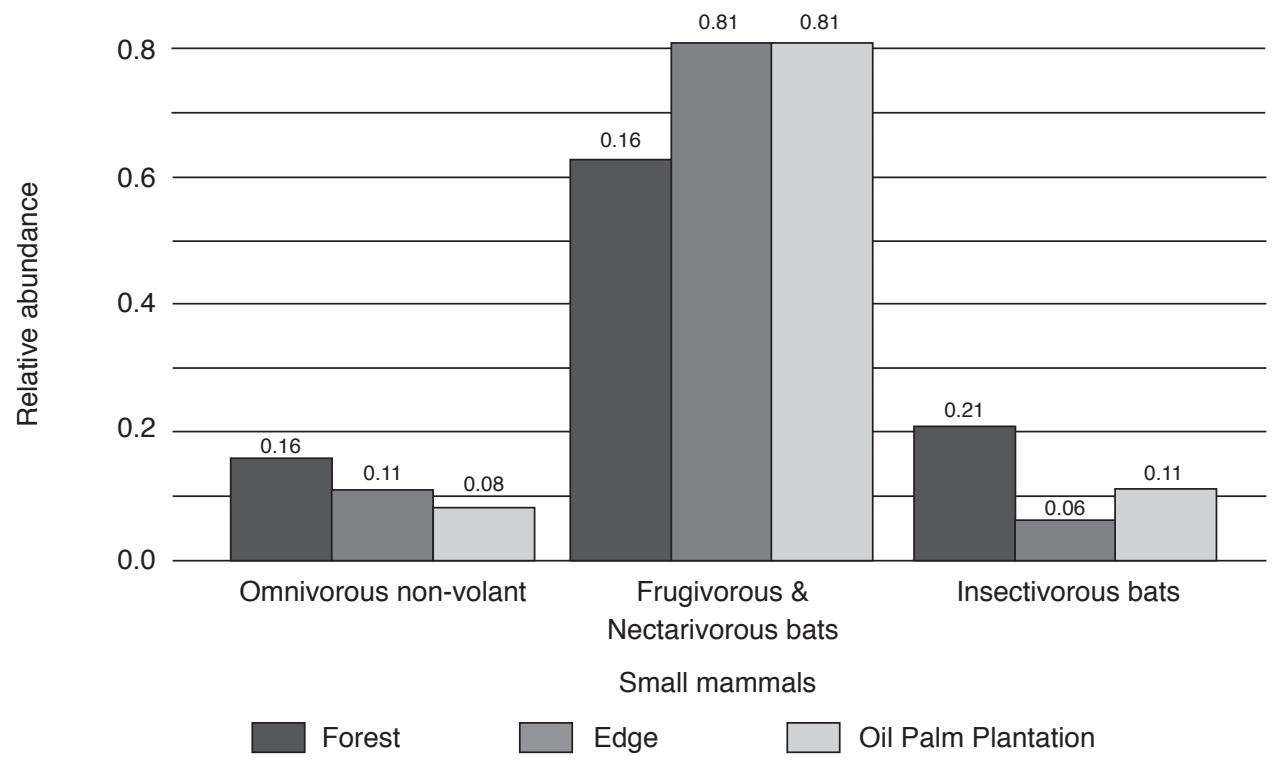

Figure 5. Graph of the recorded bat and non-volant small mammal guilds (omnivorous non-volant small mammals, frugivorous and nectarivorous bats, and insectivorous bats) across the habitat gradient in Wilmar Plantation, Miri. 
TABLE 2. SHANNON'S AND SIMPSON'S DIVERSITY

INDICES (bats, non-volant small mammals, and all species combined between Saremas HCV and Bukit Durang HCV forests)

\begin{tabular}{lcc}
\hline & Saremas 1 & Bukit Durang \\
\cline { 2 - 3 } HCV area (ha) & $\mathbf{1 1 6 . 2 8}$ & $\mathbf{9 8 9 . 2 6}$ \\
\hline \multicolumn{2}{c}{ Species richness } \\
\hline Total richness & 25 & 17 \\
Rarefaction estimate & 25 & 13 \\
\hline & \multicolumn{2}{c}{ Shannon's Index $\left(\mathrm{H}^{\prime}\right)$} \\
\hline Bats & 1.55 & 1.75 \\
Non-volant & 1.87 & 1.91 \\
Overall & 2.01 & 2.26 \\
Frugivorous bats & 0.87 & 0.85 \\
Insectivorous bats & 1.55 & 1.48 \\
Omnivorous non-volant & 1.87 & 1.91 \\
\hline & Simpson's Index (D) \\
\hline Bats & 0.67 & 0.76 \\
Non-volant & 0.80 & 0.83 \\
Overall & 0.75 & 0.84 \\
Frugivorous bats & 0.49 & 0.50 \\
Insectivorous bats & 0.67 & 0.70 \\
Omnivorous non-volant & 0.80 & 0.83 \\
\hline
\end{tabular}

Note: $\mathrm{HCV}$ - high conservation value.

\section{DISCUSSION}

In the past, research has focused on the carrying capacity of the biodiversity in oil palm plantations (Whycherly, 1961; Fitzherbert et al., 2008; Fukuda et al., 2009; Azman et al., 2011). This study successfully trapped 39 species of volant and non-volant small mammals in an oil palm plantation. Twenty-nine species (17 bats, 12 non-volant small mammals) were captured in HCV forests and 26 species (16 bats, 10 non-volant small mammals) in oil palm plantation, with 16 shared species among forest and oil palm plantation (Table 1). Thus, many forest species use the oil palm adjacent to $\mathrm{HCV}$ forests (Table 1 and Figure 3). Our findings are comparable to Shazali et al. (2016) who sampled three forest national parks in the region of Miri; 32 bats species were captured with lower effort (Niah National Park - 17 species, Lambir Hills National Park - 14 species, and Gunung Mulu National Park - 23 species). Our study shared 12 bats species with Shazali et al. (2016); no habitat specialists were detected, such as for example, Megaerops wetmorei (peat swamp specialist) or cave specialists such as Eonycteris spelaean, Rhinolophus philippinensis, Hipposideros ater). Even some locally common species, including Nycteris tragata, and Hipposideros dyacorum, were not detected. Shazali et al. (2016) recorded eight species of non-volant small mammals, with two species in Niah and Lambir Hills National Parks, and six species in Gunung Mulu National Park. Three nonvolant small mammal species that were absent in our study include the montane specialist species Sundasciurus brookei, Niveventer cremoriventer, and Leopoldamyx sabanus which is a primary forest species. This indicates HCV forests in oil palm plantation support only a fraction of the volant and non-volant small mammals that should occur there. Indeed, the numbers of species that will ultimately be supported in small HCV forests on oil palm estates is likely to be even lower still due to 'extinction debt' (Loehle and Li, 1996; Hanski and Ovaskainen, 2002). Thus, simply retaining small and isolated forest and other natural habitats in oil palm estates may be insufficient on its own to conserve all wildlife. It is clear from this study that the isolation and small size of forest patches results in species filtering and reduces species occupancy of small forests. Integration of natural habitat management into oil palm estate planning is needed, particularly the selective retention of more natural habitat than currently to create viable metapopulations (Doak and Mills, 1994; Hanski, 1994; Hanski and Ovaskainen, 2000; Lawes et al., 2000; Ferraz et al., 2007).

Vast areas of forest have been cleared for oil palm in South-east Asia with dire consequences for native wildlife. This study shows that planning oil palm landscapes to include patches of native vegetation can potentially maintain native wildlife and natural ecosystem services. The findings of this study are consistent with Edwards et al. (2010) where bird species composition was similar between forest fragments and oil palm plantation in Sabah, Borneo. However, like their study, we showed that smaller fragments offer fewer niches and support lower species richness than larger forest patches. In another study, Gibson et al. (2013) found that the species richness in smaller fragments (0.3 - $4.7 \mathrm{ha}$ ) had declined with time so that native small mammals were extirpated after $25-26$ years. By contrast, the 12 species of small mammals found in the largest surveyed forest fragment ( 56.2 ha) declined to seven species over the same period of time. The relatively similar Shannon and Simpson's indices in the present study between small and large HCV forests (Bukit Durang HCV forest is 8.5 times larger than Seramas 1) indicate that there is an extinction debt yet to be paid in Seramas 1. Connecting fragmented forests in oil palm dominated landscapes with corridors of natural vegetation, may mitigate some of the adverse effects of forest fragmentation, including extinction debt (Laurance, 2008; Edwards et al., 2010).

Fukuda et al. (2009) recorded only four species of frugivorous megachiropteran in oil palm plantation around Lambir Hills National Park, Miri, Sarawak. We recorded six species of frugivorous and nectarivorous bats (family Pteropodidae), with four species from forests and oil palm plantation, while two nectarivorous bats, the greater dawn bat (Eonycteris major, K Anderson, 1910) and dagger- 
toothed long-nosed fruit bat [Macroglossus minimus, (E Geoffroy Saint-Hilaire, 1810)] were found only at the forest edge or in oil palm plantation (Table 1). The frugivorous bats in this study also dominated the captures with 650 individuals (Table 1). This is inflated by a single species, the lesser dog-faced fruit bat (568 individuals 87\%). The lesser dog-faced fruit bat is a habitat generalist that is commonly found in disturbed areas (Abdullah et al., 1997; Hall et al., 2004; Francis, 2008). Lesser dog-faced fruit bats are known to feed on oil palm fruits (Fukuda et al., 2009). Horsfield's fruit bat (Cynopterus horsfieldii, Gray, 1843), another generalist species (Heidemann and Heaney, 1989; Francis, 2008), was absent from our study. The forest specialist fruit bats, the spottedwing fruit bat (Balionycteris maculata) and Lucas's Short-nosed Fruit Bat (Penthetor lucasi) were absent in the study by Syafiq et al. (2016), yet were recorded in the present study with higher abundance in $\mathrm{HCV}$ forests (Table 1). Bat assemblage structure changes with habitat degradation and fragmentation (Struebig et al., 2012) and the long-term survival of these generalist species (as potential ecological indicators) in an oil palm landscape should be further investigated. Insectivorous mammals perform a pest control function in agriculture reducing the prevalence of mosquito borne diseases and the need for pesticides (Phommexay et al., 2011). Frugivorous and nectarivorous mammals disperse seeds and act as pollinators; their decline may affect forest biodiversity.

We recorded fewer insectivorous than frugivorous bats in the HCV forests and oil palm plantation (Figure 5). This result is consistent with Fukuda et al. (2009) and Shafie et al. (2011), where frugivorous bats were mostly caught in oil palm plantation than in secondary forests. However, in their study, insectivorous bats were less abundant in oil palm plantation, whereas the present study found relatively similar abundance in HCV forests $(\mathrm{RA}=0.21)$ and oil palm plantation $(\mathrm{RA}=0.11)$ (Figure 5). Insect populations are significantly smaller in oil palm plantation compared to primary and secondary forests (Turner and Foster, 2009). The latter could plausibly explain the lower abundance of insectivorous bats in oil palm plantation. The species represented by singletons may be more vulnerable to extirpation, indeed Sedlock et al. (2008) failed to record four species of bats that were scarce 17 years previously. Additionally, the Near Threatened and forest dependent Malayan free-tailed bat (Mops mops) was recorded only in oil palm plantation (Table 1). This species was observed roosting in a hollow tree trunk in the oil palm estate, suggesting it can tolerate monoculture conditions given favourable roosting conditions.

Most of the non-volant small mammals' species were recorded from the forest $(n=13$, Table 1). Similarly, in a study at Lambir Hill National
Park, Sarawak, which is surrounded by agriculture, including oil palm, similar numbers of nonvolant small mammal species were recorded with no significant differences among habitat types (Nakagawa et al., 2006). Records of Near Threatened and Vulnerable species (IUCN, 2019) from $\mathrm{HCV}$ forests further highlights the importance of conserving these areas on oil palm plantations as refugia for species that are forest-dependent. However, the absence of species of conservation importance demonstrates that $\mathrm{HCV}$ forests are no substitute for large continuous forest. Determining critical forest fragment size for conserving species of conservation importance is a priority for planning wildlife-friendly oil palm plantations.

Overall the diversity of small mammals and their evenness of abundance was significantly greater in the HCV forests than the edge and oil palm areas (Figure 3). Diversity was lowest at the edge in all group comparisons (Figure 3). Rarefaction analyses suggest that fewer species detected at the edge (Table 1) is due to lower sampling effort at the edge. However, a more open canopy, extreme temperatures, wind patterns, humidity and changes in foliage density which leads to vulnerability to predation, all make the edge a relatively hostile environment (Harper et al., 2005; Laurance, 2008). In addition, the edge in this study was sharp and less of an ecotonal transition than would occur at a natural forest boundary.

Surprisingly, the large Bukit Durang forest was notably less species rich than the much smaller Saremas 1. This does not appear to be consequence of sampling effort (Figure 2a). It is possible that Bukit Durang is an old forest fragment in which, species relaxation through area- and isolation-dependent ecological filtering effects, have had sufficient time to run their course. While Saremas 1 is a more recently formed forest fragment and species relaxation hasn't occurred to any great extent. In fact, the many more species in Saremas 1 suggest that species density compensation is, for the moment, maintaining a high diversity of small mammals (Mohd-Azlan and Lawes, 2011).

These results emphasise the importance of maintaining a network of $\mathrm{HCV}$ forests, even if they are in a fragmented and monoculture dominated landscape, to conserving mammals. The HCV forests on the Wilmar Oil Palm Plantation are secondary forests. Several studies have demonstrated the conservation value and capacity of logged and secondary forest in maintaining mammal diversity (McShea et al., 2009; Velho et al., 2012; Brodie et al., 2015). Such forest fragments have conservation value only if they are actively managed to prevent further reductions in area and to promote their connectedness. Increasing the habitat heterogeneity by planting native plants, (Hodgkison et al., 2004; Syafiq et al., 2016) along the edges of the HCV 
forests may provide additional resources and also act as a buffer, to enhance the occurrence of forest dependent species.

\section{CONCLUSION}

It is important to understand how the effects of large scale land conversion to oil palm can be reduced and managed, and especially to what extent fragmented forest can be used to maintain the remaining biodiversity. Managing isolated small populations in forest fragments as part of a larger metapopulation to prevent their extirpation is the way forward. Our study shows that many forest species are thriving in these forest fragments. Improving habitat connectivity will undoubtedly facilitate the persistence of, and the very least, slow the decline (extinction debt) of small mammal communities in the plantation landscape mosaic.

\section{ACKNOWLEDGEMENT}

The authors acknowledge the support received from Wilmar International-PBB Oil Palms Berhad, Forest Department Sarawak, Sarawak Forestry Corporation, students and staff from the Faculty of Resource Science and Technology, Universiti Malaysia Sarawak. We are grateful to Simon Siburat, Kiaw Che Weng, Chang Sip Woon and Ginny Ng Siew Ling for their ideas and support. We also appreciate precious assistance from John anak Alit, James Wong Tai Hock, Azlan Liman, Levy anak Tan, Isa bin Sait, Trevor Allen anak Nyaseng, Wahap bin Marni, Nasron Ahmad, Shafri bin Semawi, Mohamad Jalani Mortada, Huzal Irwan Husin, Edward Enggu anak Setu, Golan anak Mat and Joanes anak John. Lastly, we would like to thank the anonymous reviewers for the valuable comments that greatly improved our manuscript.

\section{REFERENCES}

Abdullah, M T H; Siswanto, A; Widiyanto, A; Setiabudi and Firmansyah (1997). Abundance, diversity and distributional records of bats in disturbed habitats in Kalimantan Barat, Indonesia. Sarawak Mus. J., 11: 75-84.

Azhar, B; Saadun, N; Prideaux, M and Lindenmayer, D B (2017). The global palm oil sector must change to save biodiversity and improve food security in the tropics. J Environ. Manage., 203: 457-466.

Azman, N M; Latip, N S A; Sah, S A M; Akil, M A M M; Shafie, N J and Khairuddin, N L (2011). Avian diversity and feeding guilds in a secondary forest, an oil palm plantation and a paddy field in riparian areas of the Kerian River Basin, Perak, Malaysia. Trop. Life Sci. Res., 22(2): 45-64.

Baselga, A and Orme, C D L (2012). Betapart: An R package for the study of beta diversity. Methods in Ecology and Evolution, 3(5): 808-812.

Bray, J R and Curtis, J T (1957). An ordination of the upland forest communities of Southern Wisconsin. Ecol Monogr., 27(4): 326-349. DOI: 10.2307/1942268.

Brodie, J F (2016). Synergistic effects of climate change and agricultural land use on mammals. Front. Ecol. Environ., 14(1): 20-26.

Brodie, J F; Helmy, O E; Mohd-Azlan, J; Granados, A; Bernard, H; Giordano, A J and Zipkin, E (2017). Models for assessing local-scale co-abundance of animal species while accounting for differential detectability and varied responses to the environment. Biotropica, 50(1): 5-15. DOI:10.1111/ btp. 12500 .

Brodie, J; Giordano, A J; Zipkin, E F; Bernard, H; Mohd-Azlan, J and Ambu, L (2015). Correlation and persistence of hunting and logging impacts on tropical rainforest mammals. Conserv. Biol., 29(1): 110-121. DOI: https: / / doi.org/10.1111/ cobi.12389.

Canale, G R; Peres, C A; Guidorizzi, C E; Gatto, C A F and Kierulff, M C M (2012). Pervasive defaunation of forest remnants in a tropical biodiversity hotspot. PLoS ONE, 7(8): e41671. DOI:10.1371/journal. pone.0041671.

Colwell, R K; Chao, A N J; Gotelli, S Y L; Mao, C X; Chazdon, R L and Longino, J T (2012). Models and estimators linking individual-based and samplebased rarefaction, extrapolation, and comparison of assemblages. J. Plant Ecology, 5: 3-21.

Colwell, R K (2013). EstimateS: Statistical Estimation of Species Richness and Shared Species from Samples. Version 9. http:/ / purl.oclc.org/estimates.

Doak, D F and Mills, L S (1994). A useful role for theory in conservation. Ecology, 75(3): 615-626.

Dray, S and Dufour, A B (2007). The ade4 package: Implementing the duality diagram for ecologists. J. Statistical Software, 22(4): 1-20.

Edwards, D P; Fisher, B and Wilcove, D S (2012). High conservation value or high confusion value? Sustainable agriculture and biodiversity conservation in the tropics. Conserv Lett., 5(1): 20-27.

Edwards, D P; Hodgson, J A; Hamer, K C; Mitchell, S L; Ahmad, A H; Cornell, S J and Wilcove, D S 
(2010). Wildlife-friendly oil palm plantations fail to protect biodiversity effectively. Conserv. Lett., 3(4): 236-242.

Ferraz, G; Nichols, J D; Hines, J E; Stouffer, P C; Bierregaard, R O and Lovejoy, T E (2007). A largescale deforestation experiment: Effects of patch area and isolation on Amazon birds. Science, 315: 238-241.

Fitzherbert, E B; Struebig, M J; Morel, A; Danielsen, F; Brühl, C A; Donald, P F and Phalan, B (2008). How will oil palm expansion affect biodiversity? Trends Ecol. Evol., 23: 538-545.

Foley, J A; Ramankutty, N; Brauman, K A; Cassidy, E S; Gerber, J S; Johnston, M; Mueller, N D; O'Connell, C; Ray, D K; West, P C; Balzer, C; Bennett, E M; Carpenter, S R; Hill, J; Monfreda, C; Polasky, S; Rockstrom, J; Sheehan, J; Siebert, S; Tilman, D and Zaks, D P M (2011). Solutions for a cultivated planet. Nature, 478: 337-342.

Francis, C M (2008). A Guide to the Mammals of Southeast Asia. New Holland Publishers United Ltd, UK. p. 328-345.

Fukuda, D; Tisen, O B; Momose, K and Sakai, S (2009). Bat diversity in the vegetation mosaic around a lowland dipterocarp forest of Borneo. Raffles Bull. Zool., 57(1): 213-221.

Gaveau, D L; Sloan, S; Molidena, E; Yaen, H; Sheil, D; Abram, N K; Ancrenaz, M; Nasi, R; Quimones, M; Wielaard, N and Meijaard, E (2014). Four decades of forest persistence, clearance and logging on Borneo. PLoS ONE, 9(7): e101654. DOI: https: / / doi. org/10.1371/journal.pone.0101654.

Ghazali, A; Asmah, S; Syafiq, M; Yahya, M; Aziz, N; Peng, T; Norhisham, A R; Puan, C L; Turner, E C and Azhar, B (2016). Effects of monoculture and polyculture farming in oil palm smallholdings on terrestrial arthropod diversity. J. Asia Pac. Entomol., 19(2): 415-421.

Gibson, L; Lynam, A J; Bradshaw, C J; He, F; Bickford, D P; Woodruff, D S; Bumrungsri, S and Laurance, W F (2013). Near-complete extinction of native small mammal fauna 25 years after forest fragmentation. Science, 341(6153): 1508-1510.

Gotelli, N J and Colwell, R K (2001). Quantifying biodiversity: Procedures and pitfalls in the measurement and comparison of species richness. Ecol Lett., 4(4): 379-391.

Grenié, M; Denelle, P; Tucker, C M; Munoz, F and Violle, C (2017). Funrar: An R package to characterize functional rarity. Diversity and Distributions, 23(12): 1365-1371.
Haas, A; Hertwig, S and Das, I (2013). Frogs of Borneo -The Frogs of East Malaysia and their Larval Forms: An Online Photographic Guide. Zoological Museum Hamburg, Hamburg.

Hall, L S; Grigg, G G; Moritz, C; Ketol B; Sait I; Marni, W and Abdullah, M T (2004). Biogeography of fruit bats in Southeast Asia. Sarawak Mus. J., 80: 191-284.

Hanski, I and Ovaskainen, O (2000). The metapopulation capacity of a fragmented landscape. Nature, 404: 755-758.

Hanski, I and Ovaskainen, O (2002). Extinction debt at extinction threshold. Conservation Biology, 16: 666673.

Hanski, I (1994). Patch-occupancy dynamics in fragmented landscapes. Trends in Ecology and Evolution, 9: 131-135.

Harper, K A; Macdonald, S E; Burton, P J; Chen, J; Brosofske, K D; Saunders, S C; Euskirchen, E S; Roberts, D A R; Jaiteh, M S and Esseen, P A (2005). Edge influence on forest structure and composition in fragmented landscapes. Conserv. Biol., 19(3): 768782.

Heidemann, P D and Heaney, L R (1989). Population biology and estimates of abundance of fruit bats (Pteropodidae) in Phillippine submontane rainforest. J. Zool., 218(4): 565-586.

Hodgkison, R; Balding, S T; Zubaid, A and Kunz, T H (2004). Temporal variation in the relative abundance of fruit bats (Megachiroptera:Pteropodidae) in relation to the availability of food in a lowland Malaysian rainforest. Biotropica, 36(4): 522-533.

IUCN (2019). IUCN Red List of Threatened Species. Version 2019-1. International Union for Conservation of Nature, Gland, Switzerland. https://www. iucnredlist.org, accesed on 24 March 2019.

Keylock, C J (2005). Simpson Diversity and the Shannon-Weaver Index as special cases of a generalized entropy. Oikos, 109(1): 203-207.

Kinnaird, M F; Sanderson, E W; O'Brien, T G; Wibisono, H T and Woolmer, G (2003). Deforestation trends in a tropical landscape and implications for endangered large mammals. Conserv. Biol., 17: 245257.

Koh, L P and Sodhi, N S (2010). Conserving Southeast Asia's imperiled biodiversity: Scientific, management, and policy challenges. Biodivers. Conserv., 19: 913-917. 
Koh, L P and Wilcove, D S (2008). Is oil palm agriculture really destroying tropical biodiversity? Conserv. Lett., 1: 60-64.

Laurance, W F (2008). Theory meets reality: How habitat fragmentation research has transcended island biogeographic theory. Biol. Conserv., 141(7): 1731-1744.

Lawes, M J, Mealin, P E and Piper, S E (2000). Patch occupancy and potential metapopulation dynamics of three forest mammals in fragmented Afromontane forest in South Africa. Conservation Biology, 14: 10881098.

Loehle, C and Li, B L (1996). Habitat destruction and the extinction debt revisited. Ecological Applications, 6: 784-789.

MPOB (2017). Oil palm planted area 2017[PDF File]. http:// bepi.mpob.gov.my/index.php/en/ statistics/area/188-area-2017.html, accessed on 2 March 2019.

McShea, W J; Stewart, C; Peterson, L; Erb, P; Stuebing, R and Giman, B (2009). The importance of secondary forest blocks for terrestrial mammals within an Acacia/secondary forest matrix in Sarawak, Malaysia. Biol. Conserv., 142(12): 3108-3119.

Michalski, F, and Peres, C A (2005). Anthropogenic determinants of primate and carnivore local extinctions in a fragmented forest landscape of southern Amazonia. Biological Conservation, 124(3): 383-396.

Mohd-Azlan, J and Lawes, M J (2012). The Efficacy of Protected Areas and Future Challenges for Wildlife Conservation in Sarawak (Mazlin Mokhtar and Sharina Abdul Halim eds.). p. 136-146.

Mohd-Azlan, J and Michael J Lawes (2011). The effect of the surrounding landscape matrix on mangrove bird community assembly in north Australia. Biological Conservation, 144: 2134-2141.

Myers, S and Allen, R (2009). A Field Guide to the Birds of Borneo. New Holland Publisher, London. 272 pp.

Myers, N; Mi Ermeier, R A; Mi Ermeier, C G; Da Fonseca, G A B and Kent, J (2000). Biodiversity hotspots for conservation priorities. Nature, 403: 853-858.

Nagendra, H (2002). Opposite trends in response for the Shannon and Simpson indices of landscape diversity. Appl. Georg., 22(2): 175-186.

Nakagawa, M; Miguchi, H and Nakashizuka, T (2006). The effects of various forest uses on small mammal communities in Sarawak, Malaysia. For. Ecol. Manag., 231(1-3): 55-62.

Oksanen, J (2011). Multivariate analysis of ecological communitie. R: Vegan tutorial. $R$ Package Version, 1(7): 11-12.

Oksanen, J; Kindt, R; Legendre, P; O'Hara, B; Stevens, M H H; Oksanen, M J and Suggests, M (2007). The vegan package. Community Ecology Package, 10: 631-637.

Paoli, G D; Yaap, B; Wells, P L and Sileuw, A (2010). CSR, oil palm and the RSPO: Translating boardroom philosophy into conservation action on the ground. Trop. Conserv. Sci., 3(4): 438-446.

Peet, R K (1975). Relative diversity indices. Ecology, 56(2): 496-498.

Peres, C A (2001). Synergistic effects of subsistence hunting and habitat fragmentation on Amazonian forest vertebrates. Conservation Biology, 15(6): 14901505.

Petrenko, C; Paltseva, J and Searle, S (2016). Ecological Impacts of Palm Oil Expansion in Indonesia. Washington (US): International Council on Clean Transportation. $28 \mathrm{pp}$.

Phillipps, Q and Phillipps, K (2016). Phillipps' Field Guide to the Mammals of Borneo and their Ecology: Sabah, Sarawak, Brunei and Kalimantan. Princeton University Press. 384 pp.

Phommexay, P; Satasook, C; Bates, P; Pearch, M and Bumrungsri, S (2011). The impact of rubber plantations on the diversity and activity of understorey insectivorous bats in southern Thailand. Biodiversity and Conservation, 20(7): 1441-1456.

R Core Team (2017). R: A language and environment for statistical computing. R Foundation for Statistical Computing, Vienna, Austria. https://www.Rproject.org/, accessed on 1 March 2019.

Rajaratnam, R; Sunquist, M; Rajaratnam, L and Ambu, L (2007). Diet and habitat selection of the leopard cat (Prionailurus bengalensis borneoensis) in an agricultural landscape in Sabah, Malaysian Borneo. J. Tropical Ecology, 23(2): 209-217.

Sasidhran, S; Adila, N; Hamdan, M S; Samantha, L D; Aziz, N; Kamarudin, N; Puan, C L; Turner, E and Azhar, B (2016). Habitat occupancy patterns and activity rate of native mammals in tropical fragmented peat swamp reserves in Peninsular Malaysia. For. Ecol. Manage., 363: 140-148. 
Sedlock, J L; Weyandt, S E; Cororan, L; Damerow, M; Hwa, S H and Pauli, B (2008). Bat diversity in tropical forest and agro-pastoral habitats within a protected area in the Philippines. Acta Chiropterologica, 10(2): 349-358.

Shafie, N J; Sah, S A M, Latip, N S A; Azman, N M and Khairuddin, N L (2011). Diversity pattern of bats at two contrasting habitat types along Kerian River, Perak, Malaysia. Trop. Life Sci. Res., 22(2): 13.

Shazali, N; Khalik, M Z; Rahman, S H; Azhar, I; Khan, F A A; Tahir, N A; Murni, R; Latip, N A; Naharuddin, N; Azhar, I; McArthur, E; Khalik, M Z; Mohd-Ridwan, A R; Khan, F A A and Tingga, R C $\mathrm{T}$ (2016). Small mammals from Miri, north eastern region of Sarawak, Malaysian Borneo: Note on new locality records. Check List, 12: 1.

Sodhi, N S; Lee, T M; Koh, L P and Brook, B W (2009). A meta-analysis of the impact of anthropogenic forest disturbance on Southeast Asia's biotas. Biotropica., 41(1): 103-109.

Stibig, H J; Achard, F; Carboni, S; Rasi, R and Miettinen, J (2014). Change in tropical forest cover of Southeast Asia from 1990 to 2010. Biogeosciences, 11: 247-258.

Struebig, M J; Bożek, M; Hildebrand, J; Rossiter, S J and Lane, D J W (2012). Bat diversity in the lowland forests of the heart of Borneo. Biodivers. Conserv., 21: 3711.

Syafiq, M; Atiqah, A R N; Ghazali, A; Asmah, S; Yahya, M S; Aziz, N; Puan, C L and Azhar, B (2016). Responses of tropical fruit bats to monoculture and polyculture farming in oil palm smallholdings. Acta Oecologica, 74: 11-18.

Turner, E C and Foster, W A (2009). The impact of forest conversion to oil palm on arthropod abundance and biomass in Sabah, Malaysia. J. Tropical Ecology, 25(1): 23-30.

Velho, N; Karanth, K K and Laurance, W F (2012). Hunting: A serious and understudied threat in India, a globally significant conservation region. Biol. Conserv., 148(1): 210-215. DOI:https://doi. org / 10.1016/j.biocon.2012.01.022.

Whycherly, P R (1961). Conservation in plantation agriculture. Malayan Nature Society, 21: 43-47.

Wilcove, D S and Koh, L P (2010). Addressing the threats to biodiversity from oil-palm agriculture. Biodiversity and Conservation, 19(4): 999-1007.

Yue, S; Brodie, J F; Zipkin, E F and Bernard, H (2015). Oil palm plantations fail to support mammal diversity. Ecol. Appl., 25(8): 2285-2292. 